\title{
Firm Behavior and the Evolution of Activism: Strategic Decisions and the Emergence of Protest in U.S. Communities
}

\author{
Alessandro Piazza (corresponding author) \\ Jesse H. Jones School of Business \\ Department of Strategy and Environment \\ 6100 Main St \\ Houston, TX 77005, USA \\ alessandro.piazza@,rice.edu \\ ORCID: 0000-0002-5492-2647 \\ Fabrizio Perretti \\ Department of Management and Technology \\ Bocconi University \\ Via Röntgen, 1, 20136 Milan, Italy \\ fabrizio.perretti@,unibocconi.it \\ ORCID: 0000-0002-9073-4774
}

Running Head: Firm Behavior and the Evolution of Activism

Keywords: activism, stakeholder theory, social movement, critical events, spillovers 
Research summary. How do firms' strategic decisions affect the emergence and evolution of activism? We examine this question through a study of protests against nuclear power plants in the United States. We find that the decision to cancel construction of a nuclear unit-a substantial victory for activists - is associated with an upsurge in anti-nuclear protest activity, as emboldened activists stay mobilized even once the level of threat abates. We also find that when a firm decides to complete a nuclear power plant, thereby marking a defeat for activists, anti-nuclear protests wind down and we witness an increase in mobilization towards other causes. We discuss the implications of our findings for the study of the interaction between social movements and firms.

Managerial summary. The interaction between firms and activists is markedly strategic, and episodes of confrontation are often rooted in decisions made by firms. In this article, we examine how decisions taken by firms might impact activism in local communities through a comprehensive study of mobilization targeting nuclear power plants in the United States between 1960 and 1995. We find that when a firm cancels a proposed nuclear unit, anti-nuclear protest activity increases, as emboldened activist press the advantage. When a firm decides to complete a nuclear power plant, however, thereby defeated activists will demobilize and focus their attention on other causes. Companies should thus carefully consider how their decisions might affect activist mobilization, especially in contexts where opposition from local communities is a significant factor.

\section{INTRODUCTION}

In 1958, Pacific Gas \& Electric (PG\&E) — the largest electric utility company in Northern California at the time-made public its plans to build the first commercially viable nuclear power plant in the U.S. at Bodega Bay, a fishing village north of San Francisco. While the area had no prior history of activism, and despite nuclear power's then-ascendant trajectory, a colorful coalition of local grassroots activists soon came together, comprising "students, ranchers, dairymen, former communists, far-right libertarians, musicians, young parents, a local waitress and veterinarian, a marine biologist, and even an ornery woman who occasionally carried a shotgun" (Daly, 2015). After a six-year battle with PG\&E the coalition ultimately prevailed, and the company canceled plans for the plant in 1964. Partly due to the success of these early activists in stopping the construction of nuclear power plants in different locations_-a nationwide movement opposing nuclear power was soon born (Wellock, 1998).

Not all such efforts, however, met with a similar degree of success. In 1976, despite vocal public opposition throughout New England, the Nuclear Regulatory Commission (NRC) had issued a construction permit for a new nuclear power plant in Seabrook, New Hampshire. In response, a 
group of anti-nuclear campaigners that called itself the Clamshell Alliance-which was inspired by an extraordinary protest in West Germany that had forced the government to abandon plans to build a nuclear reactor-mobilized in opposition. Despite creative tactics, extensive mobilization, and substantial media coverage, the activists were not able to stop the construction of the plant (which was completed in 1986) and ultimately lost the fight — the Seabrook Nuclear Plant did eventually begin operation, although not until 1990. Despite their failure in achieving their goal, however, the Seabrook protests connected and inspired people around the country, establishing a dominant model of largescale direct-action organizing for many groups championing different issues (Kauffman, 2017). For instance, the AIDS activist group ACT UP also used a version of this model when it organized bold takeovers of the headquarters of the Food and Drug Administration in 1988 and the National Institutes of Health in 1990, to pressure both institutions to take swifter action toward approving experimental AIDS medications.

While the wave of anti-nuclear protests that swept the United States over several decades exhibits a great degree of variance in terms of geography and social actors involved, Bodega Bay and Seabrook largely exemplify the potential outcomes of such activism. In fact, approximately half of all reactors that were licensed by the Nuclear Regulatory Commission (NRC) in the United States were never completed, and in many cases the utility companies did not even begin construction. While many utilities simply gave up on their plans and on the associated investment, many others decided to stick to their projects and redouble their efforts to see the proposed units to completion. Decisions such as these were of course, highly consequential for the communities in which the units were sited, and especially so for anti-nuclear activists, because the achievement of their goals hinged precisely on such decisions. In turn, the examples of Bodega Bay and Seabrook highlight that whether firms cave to activist pressures is likely to have a far-reaching impact on the structure on mobilization at the local level, galvanizing or depressing protest activity not only on the focal issue, but on other issues, as well. 
In this paper, our goal is to systematically examine the consequences of strategic decisions taken by firms on the evolution of activism in local communities.

The fact that organizations and firms are potential sites and targets of activism is well-known in the literature (Clemens and Minkoff, 2004), but in approaching this topic, existing work on the contentious encounters between activists and firms (King and Soule, 2007; King and Pearce, 2010; Soule, 2012) has maintained a fairly narrow focus on firm responses to activist pressures (e.g. Eesley and Lenox 2006; Lenox and Eesley 2009; Pacheco and Dean 2015). This focus has come_-we argueat the expense of a proper appreciation of the key role firms' decisions also play in shaping activists' reactions. While such work enhances our understanding of firms' reactions to social movement pressures, still relatively little is known about how, conversely, firm decisions may shape mobilization efforts. In fact, once mobilization has arisen and firms are involved in a contentious interaction with activists, firms' decisions often represent critical events and turning points (Staggenborg, 1993) within an ongoing struggle, with broad implications for subsequent activism efforts, and their potential impact on the focal firms and beyond. In exploring such turning points, we propose that firms' decisions that signal the beginning and the end of a local conflict will have an impact on the evolution of activism in local communities. In particular, we expect firms' decisions that mark victories by activists to have a galvanizing effect on local activism, increasing the volume of protests even further. On the opposite side, we argue that firms' decisions that constitute defeats for activists will have a dual effect: reducing protest against firm activities on the one hand, while favoring the mobilization of activists towards other causes on the other.

Empirically, we explore these ideas in the context of mobilization against nuclear power in the United States, and more specifically at the impact of electric utilities' decisions to cancel or complete a new nuclear unit on protest levels in local communities. In the remainder of the paper, we first delve into the specificities of our empirical setting, in order to provide some context about the history of 
nuclear power in the United States, as well as the opposition to it, both of which began in the late 1950s. We then build on existing work on the strategic interaction between activists and firms (Baron, 2001, 2003) to develop hypotheses concerning the linkage between firm behavior, the way in which firm decisions mark turning points, and the evolution of local activism. Finally, we discuss our data and the details of our empirical analyses, we present our results, and we elaborate on their implications for the study of the strategic interaction between firms and activists.

\section{CONTEXT}

\subsection{Electric utilities and the U.S. commercial nuclear power program}

On July 16, 1945, during the final stage of World War II, the United States set off the world's first atomic test explosion and detonated two nuclear devices over the Japanese cities of Hiroshima and Nagasaki shortly after. The United States' monopoly of atomic power lasted just a few years, soon followed by other allies (Great Britain and Canada) and enemies (the Soviet Union). The technology for nuclear power generation was borrowed from such bomb-producing reactors and its transfer from military to civilian uses was strongly incentivized following President Eisenhower's "Atom for Peace" speech (1953), which advocated taking the power of the atom "out of the hands of soldiers and put it in the hands of those who will know how to strip its military casing and adapt it to the arts of peace", such as atomic energy for the benefit of all mankind.

In the United States, business magazines regularly printed information and speculation on the future of atomic energy, but most businessmen were cautious, with no inclination-even with the availability of free military technology — to invest much money yet. Reactors were expensive to build and risky to operate, especially when supplies of conventional fuel, such as coal and oil, were plentiful and cheap. At the same time, each decade saw the demand for electricity doubling and, in some other nations, government and business leaders appeared strongly inclined to pursue nuclear power. In Europe and Japan, most coal mines were gone, the best hydroelectric sites were already in use, and 
almost every barrel of oil was imported. Atomic scientist of every nation promised to solve the problem with nuclear power, and it seemed that uranium might someday become the cheapest source of energy. In the United States, when the Atomic Energy Act of 1954 started regulating the civilian uses of nuclear materials, few enterprising men resolved not to be left behind when the atomic revolution arrived.

The first commercial nuclear power plant was opened in Pennsylvania in 1958, and many others all over the country soon followed it. While in its first few years the growth of nuclear power occurred at a measured pace and not as quickly as its advocates had hoped, by the mid-1960s the industry experienced a surge in reactor orders. Such rapid growth was largely due to utility companies seeing this new form of electricity production as economical, clean and environmentally safe. Interest in nuclear power eventually peaked in the early 1970s, with over 90 new units planned for construction; as a result, the number of operational units more than tripled between 1970 and 1980 . However, the fortunes of nuclear power drastically changed starting in the late 1970s due to a complex interplay of factors including social movement opposition, the turning tide of public opinion, increased regulatory hurdles, cost escalation, the surge in inflation and the economic slowdown, as well as the accidents at Three Mile Island (1979) and Chernobyl, USSR (1986). While the number of operational units continued to rise, orders plummeted and cancellations boomed, so that approximately half of all nuclear units proposed by the mid-1990s were ultimately cancelled (Piazza and Perretti, 2015). In the 1980s, only a few new reactors were connected to the grid, and no new nuclear units came into service between 1996 and 2016. Other countries—-such as France, Japan and Russia- where nuclear power generation has historically been financed and overseen by the state or by state-run companies and whose systems for licensing reactors were highly centralized, did not experience the same trend. On the contrary, in the United States nuclear reactors have been almost exclusively owned and operated by private enterprises and its licensing system, with its numerous rival local and national authorities 
and mazes of public hearings, left many openings for endless obstruction by determined groups of opponents (Weart, 2012).

New nuclear generating units have historically been subjected to a lengthy regulatory process, initially governed by the Atomic Energy Commission (AEC) - the federal agency primarily responsible for the safety of the technology and for devising licensing procedures - and then replaced by the Nuclear Regulatory Commission (NRC), when the Energy Reorganization Act became law in 1974. The 1954 Atomic Energy Act outlined a two-step process for licensing privately owned reactors. Electric utility companies interested in building a nuclear power plant must first choose a site and a reactor design — either separately or together-and then apply for a construction permit. The application is a public document and it is generally accompanied by hearings, so it is often the first visible sign of a company's intention to build. After the utility completed the construction and the AEC/NRC determined that the plant fully met safety requirements, the applicant would receive an operating license to load the nuclear fuel and begin operation. Such arrangement was devised to provide the necessary flexibility during the early stage of the technology, when technical uncertainties regarding reactor engineering and the commitment to the rapid development of atomic power precluded the possibility of formulating universal standards. This also meant that once the necessary permits had been secured, completing the plant—or, conversely, choosing not to do so—was mostly within the purview of the electric utilities which owned it.

\subsection{The anti-nuclear movement in the United States}

Despite widespread public support for nuclear power in the early days of the technology, mobilization against nuclear power began to emerge in the late 1950s. The earliest and most consequential clashes between activists and electric utilities took place in California over the proposed construction of nuclear plants at Bodega Bay (1958), followed by Diablo Canyon (1968) and Malibu (1970). Organized opposition to nuclear power was initially sporadic, localized and contingent. The battle for Bodega 
Bay, for example, was pursued by a coalition of local citizens, sympathetic politicians, conservationists, and scientists, who first objected to the violation of aesthetic values of the area the plant would represent. But soon they expanded their critique to questions of reactor safety and, by 1963, the Northern California Association to Preserve Bodega Bay was transformed from a disorganized band of a dozen individuals into a force of nearly two thousand members with a budget of ten thousand dollars. The organization that stopped the Bodega reactor was the forerunner of the kind of coalition that would form a decade later against many nuclear plants (Wellock, 1998).

The increase in antinuclear activism went hand in hand with the expansion of the industry during the late 1960s. While most of the plants built during the bandwagon market years met with little or no opposition, several triggered strong dissent. Although there was no organized, broad-based movement against nuclear power, the cumulative effect of such antinuclear activities called attention to reservations about nuclear technology in general. Amid the wave of nuclear orders and the excitement of an industry coming of age in the Sixties, the image of the atom as a clean shiny new technology of the future was somehow lost and the public's desire to preserve local scenic beauty was also joined by its fear that perhaps society could not control the destructive force unleashed by technology. American citizens soon moved beyond a simple preoccupation with preserving nature to demanding an environment that was also free from industrial pollution, pesticides, and radioactive fallout. Eroding support for and growing protests against nuclear power were thus closely tied to increasing public fear of exposure to radiation (Walker, 2006; Weart, 2012).

The growth of the nuclear industry occurred simultaneously with the rise of the environmental movement in the United States. While recognizing the advantages of nuclear power over coal in reducing air pollution, environmentalists became increasingly critical of the technology on other grounds, such as the effects of waste heat from nuclear plants on water quality (widely known as thermal pollution), and especially about reactor safety and the catastrophic dangers of a core meltdown 
that could lead to the so-called "China syndrome". While many environmental groups pursued issues unrelated to nuclear power, they formed a crucial component of the antinuclear coalition. The Sierra Club, for example, was an organization of 140,000 members that addressed a wide range of environmental questions. The Natural Resources Defense Council (NRDC) was founded in 1969 as a "public interest law firm" to take legal action on environmental issues. Its goal was to advance environmental protection through "responsible militancy" and by 1976, it had enlisted about 15,000 members and litigated on matters ranging from administration of antipollution legislation to cleanup of industrial sites. The Union of Concerned Scientists (UCS) was formed at the Massachusetts Institute of Technology in late 1968. It began largely as a faculty organization that published an appeal in March 1969 to use science and technology for addressing social and environmental problems and increasingly became involved in the debate over nuclear power.

Although the individuals and groups who opposed nuclear power, or at least objected to specific nuclear projects, did not constitute a monolithic front in their tactics or motivation, by the mid-1970s, antinuclear activism had moved beyond localized protests and politics to gain wider appeal and influence. While it lacked a single coordinating organization and uniform goals, it emerged as a movement sharply focused on fighting nuclear power and its efforts attracted a great deal of national attention. Some prominent critics of nuclear power who first became involved in opposing local projects also branched out to gain recognition as national antinuclear leaders. And while individuals on the left with strong progressive and collective ideals would remain the most consistently opposed to nuclear power, conservatives also demonstrated that when their private interests - such as family safety, quality of life, and property values-were threatened, they too would turn against the atom. Nuclear opposition thus expanded beyond its environmental origins to include other groups transcending ideological categories and, in the 1970s, the single-issue groups-forerunners of NIMBY (Not in my Backyard) mobilization—would come to dominate a decentralized antinuclear coalition. 
Although the battle over nuclear power was usually fought in press conferences, hearings, meetings, petitions, articles, and television appearances, it also manifested itself in the form of more direct confrontations: between 1960 and 1995 the New York Times reported no fewer than 341 distinct anti-nuclear protest events that took place all over the country, whose temporal evolution is reported in Figure 1.

Insert Figure 1 about here

The anti-nuclear cause was also helped by the occurrence of traumatic events such as nuclear accidents (Nelkin, 1981; Walker, 2006; Walsh, 1981, 1986). Figure 1 shows how anti-nuclear protests began gaining traction after 1975 and eventually peaked in correspondence of the Three Mile Island accident in 1979 (Nelkin, 1981; Walsh, 1986) that brought the issue of nuclear power into the forefront of the national debate.

\section{THEORY}

\subsection{Firms' decisions as victories for activists}

In the past few decades, explaining the determinants of successful outcomes (both in terms of the incidence and the result of mobilization) has been one of the central concerns of the social movement literature (Eesley, Decelles, and Lenox, 2016; Gamson, 1975; Luders, 2006). In parallel, the management literature has also examined the conditions under which activists are able to elicit a response from the firms they target (e.g. see Eesley and Lenox 2006; Pacheco and Dean 2015). Yet given the variety of forms that outcomes can take in this context, and given that many activist groups often set rather ambitious goals, success is typically best conceptualized as incremental (Gupta, 2009). Even though a group might fall short of achieving the totality of its goals, incremental successes are still beneficial in that they spur mobilization and further growth. 
Local victories can be considered as critical events, i.e. contextually dramatic occurrences that are remarkable in that they lead to important shifts in public and elite perceptions of reality (Staggenborg, 1993) and durably transforms previous structures and practices (Sewell, 1996). In particular, critical events are key elements in the process linking an occurrence to its outcomes. This point is well captured by Schudson (1993), who argues that some events have not only the power of contingency, but also the power of continuity in shaping and influencing people's actions in the future. In the context of mobilization, critical events may lead to the formation of a new movement or may significantly reenergize an existing one (see Lee and Chan, 2011), often providing an occasion for movements to shift their focus and adjust their strategies and tactics because of changes in expectations and perceptions of threats (Staggenborg, 1993). For example, favorable turning pointssuch as the passage of legislation—showcase activism as a viable opportunity for social change so that, even though a substantial success might have been achieved, activists often remain mobilized to push further towards even more ambitious goals (Staggenborg, 1988). In such a scenario, victories typically do not result in demobilization, because if the movement goals are broad enough further collective action is always possible. Rather, activists are likely to be galvanized by their success, and the additional visibility provided by it will make it easier to convince others to join their ranks, thus making further protest activity more likely. For instance, the teacher strikes that swept the United States in early 2018_ originating in West Virginia and then expanding to other states like Oklahoma and Kentuckywere quite successful at achieving their stated goals of obtaining pay increases and better working conditions. ${ }^{1}$ This success, however, ultimately resulted in increased collective action and helped foster further mobilization by teachers nationwide. ${ }^{2}$

\footnotetext{
1 https://www.nytimes.com/2018/04/02/us/teacher-strikes-oklahoma-kentucky.html

2 https://www.theatlantic.com/education/archive/2018/03/west-virginia-teachers-victory/555056/
} 
In the case of the anti-nuclear movement, once activists are mobilized and a victory—i.e. the cancellation of a proposed nuclear unit-is achieved, we therefore expect a bandwagon effect (Gupta 2009: 419-420) to take place, resulting in further anti-nuclear mobilization. This is because: 1) successful anti-nuclear activists will develop a reputation for competence, which ultimately will result in increased access to resources and greater capabilities to mobilize support; 2) a history of success will galvanize the movement, resulting in greater expectations and the setting of more ambitious goals, which only further mobilization can achieve. A useful, context-specific example here is provided by the history of the anti-nuclear movement in the Northeastern United States. The earliest instance of mobilization against a proposed nuclear plant in this area dates back to 1974, and took place in Montague, MA, where Northeast Utilities had proposed to build a new, two-unit nuclear plant the previous year. A local farmer, Sam Lovejoy, sabotaged the plant's weather tower using farm tools and then turned himself in to the authorities, justifying his action by means of a four-page statement. Local communities eventually mobilized, and the Montague power plant was indefinitely postponed in 1975 and ultimately shelved in $1980 .{ }^{3}$ Anti-nuclear protests, however, did not abate; rather, the movement grew in size and importance. ${ }^{4}$ When another proposed power plant nearby-located in Seabrook, NH, and bordering Massachusetts_-began construction in 1976, Sam Lovejoy and other local antinuclear activists, galvanized by their recent victory at Montague, founded the Clamshell Alliance, a coalition of New England antinuclear groups. ${ }^{5}$ The Clamshell Alliance eventually organized one of the largest demonstrations in the history of the anti-nuclear movement in 1977, in which 2,000 people took part and over 1,400 trespassers were arrested at Seabrook. The events at Montague and Seabrook

\footnotetext{
3 https://nvdatabase.swarthmore.edu/content/montague-massachusetts-citizens-stop-nuclear-power-plantconstruction-united-states-1974

4 http://archive.boston.com/ae/books/articles/2009/12/30/beyond vietnam tracks protest movements with roots i n new england/

5 https://nvdatabase.swarthmore.edu/content/clamshell-alliance-campaigns-against-seabrook-nuclear-power-plantnew-hampshire-1976-1989
} 
also spurred mobilization against two neighboring power plants already in operation, which had been uncontroversial up to that point: the Vermont Yankee plant in Vernon, VT (20 miles from the Montague site) beginning in 1979, and the Yankee Rowe plant in Rowe, MA (approximately 30 miles from Montague) beginning in the early 1980 s. ${ }^{6}$ For the purposes of our theoretical framework, we then predict that nuclear unit cancellations will result in further anti-nuclear mobilization at the local level. Our formal hypothesis is thus:

Hypothesis 1. An electric utility's decision to cancel a previously proposed nuclear unit will be associated with an increase in anti-nuclear protest activity in neighboring communities.

\subsection{Firms' decisions as defeats for activists}

Not all conflicts between activists and firms are resolved positively for the former, and when activists lose a battle, a shake-up is to be expected in how collective action is organized within the community (Beckwith, 2015). Positive and negative events usually exert asymmetrical effects, with opposite cognitive, emotional and social responses (Taylor, 1991). Diametrically opposed to victories, defeats create negative signals about a group's reputation, intentions, and capacity for effecting change. Current and potential supporters use such information to update their own beliefs about the merits of allocating support to the group, making it harder for the group to access resources and engage in future mobilization and contention (Gupta, 2009). Often, failure in achieving specific goals results in the demobilization and in the downfall of established activist groups.

For instance, in a study of a black nationalist organization in the United States, Davenport (2015) argues that in the face of defeat, activist groups face a loss of trust resulting from their failure

\footnotetext{
6 https://nvdatabase.swarthmore.edu/content/us-citizens-campaign-close-nuclear-power-plant-rowe-massachusetts$\underline{1991}$
} 
to achieve their stated goals. In turn, this generates a downward spiral in which failures reduce trust and exacerbate other organizational problems including rigidity, difficulty in accessing resources, burnout, loss of commitment, and factionalization. Similar dynamics were observed in the UK during the 1984-85 miners' strikes, when most Nottinghamshire miners rejected the call to strike and continued to work and after the "Battle of Orgreave", a violent confrontation between police and pickets which took place in June 1984 at a British Steel Corporation (BSC) coking plant in Orgreave, South Yorkshire — a pivotal event and one of the most violent clashes in British industrial history. The formal end of the strike on March $3^{\text {rd }}, 1985$-which marked the National Union of Mineworkers' (NUM) defeat—was a defining moment in British industrial relations that significantly weakened the entire trade union movement (Gibbon, 1988; Howell, 2012; Phillips, 2014).

For those who get involved in social movements, defeats are quite common and the perception of failure can induce many activists simply to give up and to move to other pursuits. In the case of the anti-nuclear movement, starting from 1978, such perception was quite evident (see Moyer, 2001). Less than a year after dramatic demonstrations and mass arrests, and with only a narrow majority of public opinion against nuclear energy, some activists believed the movement was ineffective, powerless, losing, and dying out. Not one reactor had been directly stopped by nonviolent action, six new reactors had been connected to the grid, and the targets of the biggest demonstrations- the Diablo Canyon and Seabrook reactors-were still being constructed. Many activists thought the movement was losing, because it had not achieved its stated goal of stopping the construction of nuclear power plants. According to Moyer (2001), who was directly involved in the protests at the Seabrook nuclear power plant, "a serious discouraging sign for activists was that from 1978 to 1990, 42 new nuclear power plants started up - one every 18 weeks! - raising the number of operating reactors from 71 to 113. Moreover, both Diablo Canyon and Seabrook, the two reactors that most publicly defined the movement opposition to nuclear power, started operating” (p. 148). 
At a general level, we would thus argue that when a major defeat occurs, supporters are likely to lose faith in the movement and in its ability to promote change, resulting in demobilization. In the context of the conflict between anti-nuclear activists and electric utility companies, therefore, we would expect a utility's decision to complete an open project for a new plant to be associated with a decrease in local anti-nuclear protest activity. More formally:

Hypothesis 2. An electric utility's decision to complete a previously proposed new nuclear unit will be associated with a decrease in anti-nuclear protest activity in neighboring communities.

\subsection{Activism spillovers following defeat}

The idea that activists championing different causes are not independent has been around since resource mobilization theory (McCarthy and Zald, 1977); more specifically, scholars have recognized that movements compete for resources and adherents. Meyer and Whittier (1994: 277) observed that "the ideas, tactics, style, participants and organizations of one movement often spill over its boundaries to affect other social movements". Moreover, participation in activist efforts can influence people, having an impact on their identities and the way in which they construct their social world. This is likely to be a durable process, lasting even once collective action abates. Once new reasons for mobilization emerge, individuals who previously took part in mobilization are more likely to become active again and continue to see themselves as activists and to direct their efforts towards different causes. For instance, Hadden and Tarrow (2007: 360) examine how the global justice movement in the United States progressively weakened following the 1999 Seattle W'TO protests, as activists transitioned from transnational mobilization to domestic protest. The authors label this dynamic a spillout, defined as "the hollowing-out of a social movement when its activists shift their activities to a cognate, but differently structured, movement”. 
In the case of the anti-nuclear movement, this phenomenon was quite evident in France, where defeats were especially unambiguous, inasmuch as the anti-nuclear activists were not able to stop the country's nuclear power program. As of 2017, France relies on nuclear energy (72 percent of total electricity generation) more than any other country of the world. As described by Tompkins (2016), who interviewed many protesters, protest networks brought together “people who wouldn't have met if it hadn't been for the anti-nuclear movement, people who wouldn't have evolved the way they did without it" (p. 199). For many individuals, anti-nuclear protests were thus just the starting point of a trajectory of activism, and many activists who suffered their worst defeats eventually moved on to other causes (environmentalism, feminism, peace, etc.), established new organizations, created alternative infrastructures, and cultivated protest traditions beyond the issue of nuclear energy. Antinuclear protests thus served as an incubator for diverse protest traditions, catalyzing important political changes and making an impact beyond the number of power stations ultimately built.

In the case of anti-nuclear activism, following the completion of a proposed nuclear unit, which represents a major defeat for activists, we then expect to observe not only local demobilization - i.e. a decrease in anti-nuclear protest activity — but also protest spillovers (Ferguson, Dudley, and Soule, 2017; Meyer and Whittier, 1994), as former anti-nuclear activists decide to mobilize again towards different causes. Formally stated:

Hypothesis 3. An electric utility's decision to complete a previously proposed new nuclear unit will be associated with an increase in unrelated protest activity in neighboring communities.

\section{DATA AND METHODS}

To test our theory, we set up a quantitative study based on data from a number of sources. Countylevel variables were coded based on several editions of the City and County Data Book, compiled by 
the U.S. Census Bureau. These include information about all U.S. counties at regular time intervals, which were then interpolated to provide yearly data from 1960 to 1995. Additionally, all counties were individually geo-coded and assigned a pair of coordinates based on their approximate center, which we used to match the focal county to all counties within 100 miles. All information concerning proposed nuclear reactor units were obtained either from the PRIS (Power Reactor Information System) online database maintained by the International Atomic Energy Agency (IAEA) or from historical documents included in the Nuclear Regulatory Commission's (N.R.C.) Agency-wide Documents Access and Management System (ADAMS). Additionally, all nuclear units were matched to counties within 100 miles based on their respective geographical coordinates. ${ }^{7}$ The resulting dataset comprises information on the 237 units planned for construction since 1953, 108 of which were ultimately cancelled (45.6 percent), while the remainder were completed. Figure 1 depicts the temporal trends in the proposal, cancellation and completion of new nuclear units between 1953 and 1995.

Insert Figure 1 about here

Finally, data about protests was obtained from a database created at Stanford University and known as the "Dynamics of Collective Action Project", based on all New York Times (NYT) issues released in the 1960-1995 time window and covering all protest events that happened in the public sphere. Most relevant for our analysis, the database includes information about the purpose of each protest event. Protests opposing nuclear power were identified as those including the claim "AntiNuclear (Power) Movement", which yielded a subset of 341 protests in the same time interval. Overall, the dataset includes information about approximately 23,000 protest events that took place all over

\footnotetext{
7 We test the robustness of our results to the choice of distance in a separate Appendix.
} 
the United States between 1960 and 1995. Because of this, our county-level panel dataset employs the same observation window. Figure 3 provides a graphical depiction of the locations of nuclear units and anti-nuclear protests.

Insert Figure 2 about here

Some trends are immediately apparent when looking at this figure. In particular, Figure 3 shows that most proposed nuclear units were concentrated in the Northeast, Midwest, and South, while large swaths of the country remained untouched by nuclear power. Anti-nuclear protests, however, do not closely map onto the distribution of proposed units. Most protests seem to have occurred in the Northeast and near major urban areas; California and the Pacific Northwest also show a substantial number of protests, even though the number of nuclear units proposed there was fairly limited. On the other hand, the South and the Midwest experienced relatively little protest activity given the density of nuclear units proposed there, as did rural areas more generally. This could be seen either as evidence of the anti-nuclear movement being unable to mobilize effectively in those areas or, conversely, of the existence of "quiet mobilization" in support of nuclear power, possibly taking place through community action rather than public demonstrations (Jerolmack and Walker, 2018).

Insert Figure 3 about here

\subsection{Variables}

Dependent variables. For Hypotheses 1 and 2, the dependent variable is a count of antinuclear protests in year t within the focal county. To create this variable, we matched all protest events in the DOCA dataset to their respective county, and then we counted those that reported claim 0200 - "Anti 
Nuclear (Power) Movement". ${ }^{8}$ For Hypothesis 3, our dependent variable is a count of protests not targeting nuclear power in year t within the focal county, which is obtained by counting protests taking place within the county and not reporting claim 0200 .

Independent variables. The main independent variables are count variables for the number of previously proposed nuclear units that were cancelled (H1) and completed $(\mathrm{H} 2, \mathrm{H} 3)$ up to year $t-1$ within 100 miles of each local community, measured as the law-of-cosines great circle distance ("as the crow flies") between the respective pairs of coordinates (county's approximate center and nuclear unit). Here, proposed units are defined as those units that have been formally announced by an electric utility and approved by the Nuclear Regulatory Commission, regardless of whether construction has begun or not. Cancelled units are those proposed units that were later abandoned and never reached the operational stage. Conversely, completed units are those reactors that were eventually connected to the grid and began operating. For the purposes of our study, our two main independent variables are coded as follows: 1) number of cancelled nuclear units within 100 miles of the focal county up to year $t$, 2) number of completed nuclear units within 100 miles of the focal county up to year $t .{ }^{9}$

Because other factors can affect the emergence of activism, we also included a set of controls in our study. Because proposed nuclear units create perceptions of threat within neighboring communities, our models include a count variable for the number of proposed units currently under development within 100 miles of the focal county. County-level variables with the potential to affect the development of activism, as well as its characteristics, include unemployment, median income, total county population, percentage of African-Americans, as well as the percentage of college-educated individuals and the political

\footnotetext{
${ }^{8}$ For further details about the claim variable or the structure of the protest data, see: https://web.stanford.edu/group/collectiveaction/cgi-bin/drupal/

9 These variables are coded in a cumulative_ rather than "spot"-fashion because the development of anti-nuclear activism in a given community is likely to be a function of its entire history of success and failure in their efforts against nuclear power plants. Conversely, we use a spot variable for planned nuclear units and consider only units actively under development (i.e. not yet completed or cancelled), because their galvanizing effect on activism is likely to be limited to this time window.
} 
leaning of the county, measured as whether a plurality of voters chose a Republican or a Democratic candidate in the most recent presidential election. These variables have often been used to characterize the emergence and characteristics of protests in the social movement literature (e.g. Andrews, Beyerlein, and Farnum, 2015; Davenport, Soule, and Armstrong, 2011; Robnett, 1996), and were included in all models. In addition to the above, we control for past levels of anti-nuclear and unrelated activism in the county. Because these two variables were found to be highly correlated, we transformed them by means of a Gram-Schmidt orthogonalization procedure (through the use of the orthog command in STATA), so as to make them uncorrelated (Golub and Van Loan, 1996). To account for temporal, nationwide trends in the both the construction of nuclear reactors and the emergence of anti-nuclear protests, our models include variables for the number of anti-nuclear protests nationwide in the previous year, as well as for the number of reactors proposed for construction in the previous year. Finally, to account for time-invariant heterogeneity at the state level, all of our models include county fixed effects. ${ }^{10}$ Summary statistics for all the variables in our dataset are reported in Table 1, together with pairwise correlations.

Insert Table 1 about here

\subsection{Methodological approach}

Because our dependent variable for all hypotheses is a (non-negative) count of protest events, and because the variance in our dependent variables exceeds the mean-thus making Poisson regression not an option—we use negative binomial regression on our panel dataset. ${ }^{11}$ To alleviate endogeneity concerns, we lag all independent variables by one year. Another potential concern with our research

\footnotetext{
10 We test the robustness of our results to the inclusion of fixed effects by also running random effects models, reported in Tables A1 and A2 of the Appendix. The pattern of results is substantially unchanged by the inclusion of fixed effects.

11 We had initially sought to include year fixed effects in our negative binomial regression models as well. However, the models failed to converge. As a backup option, we included control variables for temporal trends in reactor construction and protest emergence at the national level. Table 4, however, reports the results of panel OLS models that do include year fixed effects.
} 
design is that the assignment of anti-nuclear protests to counties is likely non-random. This is because counties that are located near proposed nuclear power plants are overwhelmingly more likely to experience anti-nuclear protests than those which are not; in turn, assignment of proposed plants to counties is not random, either, and depends on the hydrogeological, seismic, demographic, and sociopolitical characteristics of the county. Running our models on the entire set of U.S. counties might therefore create statistical inference issues. To mitigate this concern, we define a risk set of counties susceptible to anti-nuclear mobilization and then run our models only on these. Counties are assumed to enter the risk set when a nuclear unit is first proposed for construction within 100 miles in the previous year-regardless of whether it was ultimately built or not—and to remain in the risk set afterwards. Doing so reduces the number of zero values in our dependent variable, while at the same time ensuring that our hypotheses are tested on a set of counties that is somewhat comparable, excluding the large swaths of the country (e.g. Montana, Idaho, the Dakotas) where nuclear power plants were never proposed, thereby mitigating concerns arising from nonrandom assignment of nuclear units to counties. While the original sample comprised 106,669 observations of 3,070 counties over a 35-year period (1960 to 1995), the reduced sample includes 58,734 observations of 2,025 counties over the same time period, or approximately 54 percent of the original sample.

\section{RESULTS}

Table 2 reports the results of our panel negative binomial models with the count of antinuclear protests in at-risk counties as a dependent variable. Model 1 includes county-level basic control variables, while Model 2 adds the controls related to previous protests in the county, and Model 3 adds controls for nationwide trends in nuclear reactor construction and anti-nuclear activism. Here, Model 3 suggests a bandwagon effect in nuclear protests, with nationwide trends having a positive effect on local activism, while at the same time highlighting that anti-nuclear protests predominantly 
took place at a time when most U.S. nuclear reactor units had already been planned for construction. Model 4 adds the variable for the number of planned nuclear units currently under development within 100 miles in at-risk counties. The coefficient is positive, suggesting that an additional proposed unit within 100 miles of the county is associated with an increase in anti-nuclear protest volume of $100^{*}(\exp (0.1682)-1)=18.3$ percent. ${ }^{12}$ Model 5 then adds our variable for the number of completed units within 100 miles, whose coefficient is negative, indicating that the completion of one unit under development within 100 miles is associated with a 14 percent decrease in the volume of anti-nuclear activism. Finally, our full model, Model 6, adds the variable for the number of cancelled nuclear units within 100 miles; here, the coefficient is positive, indicating that a cancellation of a nearby nuclear unit under development within 100 miles is associated with a 27 percent increase in the volume of local anti-nuclear activism. These results provide strong support for Hypotheses 1 and 2, and also show that the volume of anti-nuclear protests is a positive function of the number of planned units nearby. Insert Table 2 about here

The results of our panel fixed effects negative binomial models for protest activity unrelated to nuclear power are reported in Table 3. Once again, Model 7 includes just control variables, while Model 8 adds the variables for past protest and Model 9 the variables for nationwide trends. Model 10-12 then add the variables pertaining to local nuclear units individually. Model 11 and 12 show that completed units are positively associated with mobilization on themes unrelated to nuclear power, providing support for Hypothesis 3. For what concerns the effect size, based on Model 12 each additional completed nuclear unit is associated with a modest but significant 2.3 percent increase in the number of protests per year in counties within a 100-mile radius. This is consistent with the idea that firm decisions in the domain of nuclear power can trigger broader protest cycles, generating an increase in

\footnotetext{
12 Recall, however, that all counties in the risk set have had one unit proposed within 100 miles, so this effect is best understood as the effect of additional units beyond the first.
} 
mobilization towards other causes as well (Minkoff, 1997; Tarrow, 2011). In a similar fashion, planned and cancelled units are also associated with an increase in the number of unrelated protests—by 0.5 and 1.5 percent, respectively-but these are smaller and can hardly be separated from zero. The positive coefficient of the variable for cancelled units-which is a proxy for social movement victories-however suggests that successful mobilization against nuclear power might showcase the efficacy of activism and exert a galvanizing effect on unrelated mobilization, as well, attracting more resources to the general movement field (McPherson, 1983).

Insert Table 3 about here

It is of course possible-and likely_that the increase in unrelated protests will not benefit other causes equally, and that firm decisions will have a greater catalyzing effect on protests championing conceptually similar goals, such as protecting the environment. To test whether this is the case, we ran separate panel negative binomial models for several common types of protests: 1) opposing atomic weapons; 2) Not-In-My-Backyard (NIMBY) protests; 3) environmental protests; 4) protests targeting government policy; and 5) peace (anti-war) protests. Results for these models are reported in Table 4. Here, Model 13 shows a positive coefficient for the number of completed units, as do Models 15 and 16. This is suggestive of the fact that in the aftermath of the completion of a unit, counties tend to experience relatively more protests targeting atomic weapons, as well as protests with a government policy or NIMBY focus, although to a lesser degree.

Insert Table 4 about here

\subsection{Robustness checks.}


To test the strength of our results, we re-estimated our models using alternative model specifications. Negative binomial models do not allow for the use of Huber-White robust standard errors (White, 1980) to adjust for within-cluster correlation, and we were also unable to include year dummies, as doing so caused our models not to converge. In Table 5, we thus use the logged counts of anti-nuclear and unrelated protests as our dependent variables and estimate ordinary least squares (OLS) models; in so doing, we include robust standard errors, year dummies, and county fixed effects to control for time-invariant geographic heterogeneity. The coefficient for our independent variables and interaction terms are consistent with the patterns described above, which suggests that our results hold even under these alternative specifications. As a further and final robustness check, we re-estimated our models using generalized estimating equations (Liang and Zeger, 1986), which have several desirable properties: in particular, they accommodate correlation across time periods and they provide consistent estimates even when the correlation structure is misspecified, while still allowing for timeinvariant covariates. Once again, the results do not differ in any significant manner from those discussed above, providing further support for our hypotheses and our broader theoretical framework. Insert Table 5 about here

A second issue of concern has to do with the reliability of newspaper data (Earl et al., 2004). Our empirical analysis, in fact, hinges on the assumption that the New York Times is a representative source for what concerns national media coverage of the anti-nuclear movement. Here, we must note that the New York Times is the most frequently used source in this type of study and it has been recognized as being of high quality for the purposes of studying social movements (Ortiz et al., 2005). Moreover, the specific dataset we use has been most common choice for quantitative studies of social movements in the past couple decades (e.g. King, 2008; King \& Soule, 2007; Walker, Martin, \& McCarthy, 2008). Nonetheless, for what concerns anti-nuclear activism more specifically, it is 
conceivable that newspapers located in different parts of the country might be characterized by different levels of attention to the issue, and that the New York Times in particular might be a biased source because of the high concentration of both nuclear power generation and anti-nuclear activism in the Northeastern United States.

To test whether this is the case, we relied on an alternative data source: Newspapers.com, an online newspaper archive consisting of over 500 million pages of historical newspapers from around the United States and beyond. After obtaining access to the data, we ran a search for the word "protest" coupled with either "nuclear plant" or "nuclear power". Doing so yielded approximately 220,000 results from about 1,400 local outlets in all 50 U.S. states, with Pennsylvania (10 percent of results) and California (7.4 percent) being the most heavily represented. Figure 4 reports the distribution of articles over time, which correlates 93.3 percent with the distribution of protest events reported in the New York Times reported in Figure 1. The two curves appear remarkably similar, with the exception of a spike around 1986 in Figure 4. This is likely a byproduct of coverage of protests in the aftermath of the 1986 Chernobyl accident, and the discrepancy could be caused by the fact that the protests reported in Newspapers.com articles could have occurred abroad. Otherwise, our robustness check appears to suggest that New York Times coverage of protest events is a reasonable operationalization of protest occurrence for our purposes, and media bias is unlikely to explain away our findings.

Insert Figure 4 about here

Finally, in our modeling choices we have assumed that counties within 100 miles of a proposed nuclear reactor are at risk for anti-nuclear mobilization and have constructed our variables accordingly. While any choice of radius is ultimately arbitrary, we chose 100 miles because while in certain areas of the country, such as the Northeast, nuclear units are quite prevalent and are often located near major 
cities (see Figure 2), in others—-such as the South and West—nuclear units are quite sparse and located in relatively more rural areas, so perceptions of risk likely vary. Furthermore, while evacuation zones around U.S. nuclear reactors traditionally have a radius of 10 miles, some nuclear experts have proposed extending them to 50 miles, ${ }^{13}$ and anti-nuclear activists have long pointed out that in the case of a more serious accident resulting in a breach in the nuclear reactor containment vessel, volatile radioactive iodine can substantially increase cancer risk hundreds of miles away from the plant. Overall, setting the radius at 100 miles seemed a reasonable choice to account for all the above factors; however, we also recognize that our pattern of results might be contingent on our choice of radius. In Table A3 of our Appendix, therefore, we report results for models in which the risk set radius is set to 50 and 150 miles, which are substantially analogous to those presented in the main body of the manuscript, suggesting that our findings are robust to the choice of radius.

\section{DISCUSSION}

Current research on episodes of contention between firms and activists remains largely focused on how the former respond to the latter's efforts to mobilize. In this paper, we focus instead on how activism can be affected by firms' strategic decisions that act as turning points in such conflicts. By conceptualizing firms' decisions as victories and defeats for activists, and focusing on anti-nuclear mobilization across the United States, we found that a firm's decision to cancel a proposed nuclear unit is associated with an increase in anti-nuclear mobilization, as success galvanizes local activists and paves the ground for further protest activity. We also showed that the completion of a nuclear unit is associated with a local decrease in anti-nuclear mobilization and an increase in activism related to other issues in neighboring areas, providing evidence consistent with both demobilization and spillover

13 https://www.motheriones.com/politics/2011/03/does-us-nuclear-emergeny-planning-need-overhaul/ 
effects driven by activists' defeat. This resonates with work on protest cycles and the sequencing of social movements — notably by Tarrow (2011) and Minkoff (1997) — in that we found the effect of social movements, whether successful or failed, to be cumulative in the long term, leading to new protest cycles within and across issues.

Our findings shed light on the manifold effects that firm behavior can have on the evolution of activism at the local level, which go beyond simply catalyzing the emergence of protest. In this regard, our results show that firms decisions can be considered "critical events" in a conflict (Staggenborg, 1993) that not only determine local mobilization outcomes, but can also have boundaryspanning effects (Wang, Piazza, and Soule, 2018), which can potentially affect other related or unrelated episodes of contention in different geographical communities. Seemingly unrelated instances of mobilization within the same community are thus not necessarily independent; rather, can trigger movement spillovers (Meyer and Whittier, 1994) as well as the erosion of boundaries between movements (Wang, Rao, and Soule, 2019). At the same time, our findings show that traditional explanations concerning the lifecycle of social movements-which would hold that mobilization would be most effective at its very onset, and its efficacy would tend to wane over time (Blumer, 1969; Mauss, 1975; Tilly, 1978)—likely do not hold. Rather, social movements and firms fought protracted battles over individual units, and in some cases project cancellations took place years, if not decades, after mobilization had first arisen, indicating that protest activity was not necessarily more effective in its early stages.

Not unlike chess grandmasters who play simultaneous games against many opponents, companies with multiple locations or pursuing various projects should thus carefully consider how their decisions might affect activist mobilization beyond the focal project, and especially in contexts where opposition from local communities is a significant factor. Indeed, while extant research has examined dynamics rooted in social influence such as bandwagons (Rao, Greve, and Davis, 2001), 
recent evidence suggests that the consequences of conflicts between activists and firms might spill over to other, non-targeted firms as well (Briscoe, Gupta, and Anner, 2015; Yue, Rao, and Ingram, 2013). In our empirical setting, for instance, when community-level struggles result in outcomes such as nuclear reactor cancellations, these could be interpreted not only as victories by local activists, but also as defeats by utilities involved in nuclear power generation as a whole, with field-level, delegitimizing effects (Davis, Diekmann, and Tinsley, 1994; Hiatt, Sine, and Tolbert, 2009). If this is the case, we might then expect firm decisions such as these to diffuse to other firms in the same industry (Briscoe and Safford, 2008), leading these to follow suit.

Overall, while existing work has usefully examined the ways in which activism is interpreted by firms and then used to guide strategic decisions both by the targeted firm (Ingram, Yue, and Rao, 2010) and by other firms in the industry (Yue et al., 2013), our work complements this line of inquiry by underlining how firm strategies can also be used as cues by activists, shaping the evolution of local mobilization in the process. Since victories can be perceived as critical events and might have significant effect on future mobilization, activists need to choose their targets wisely, perhaps selecting those that are less powerful and have higher chances to be defeated. In case of defeats, mobilization could be preserved only if movement spillover opportunities exist. This means that activists should seek collaboration and links with other related movements and causes in order to build potential bridges that can be used in the worst-case scenario of local defeats.

We believe our work also makes meaningful contributions to social movement theory. To assess the extent of our contribution, however, it is useful to examine whether our findings might generalize to other settings, and specifically to the forms of activism that contemporary organizations face. In this regard, the literature on "site fights" (e.g. Aldrich 2008; McAdam and Boudet 2012; Wright and Boudet 2012) has highlighted the dynamics of contention surrounding siting decisions for a variety of projects, including liquefied natural gas (LNG) terminals, oil pipelines, and waste incinerators. In a 
similar fashion, other scholars (Ingram et al., 2010; Yue et al., 2013) have examined the strategic interactions between corporations such as Wal-Mart and anti-chain store activists, with a particular focus on how the decision to locate stores within particular communities causes activism to emerge. We would therefore expect our findings to generalize to all those settings in which firm decisions have the potential to stir up localized activism, including-but not limited to- the examples discussed above.

On the other hand, because our study focuses on mobilization within local communities, our study is less likely to generalize directly to open-ended social movements with a broader scope. Indeed, the literature on mobilization has shown that social movements - especially those who fight for people's rights or against discrimination and whose goal is legal change - can persist in the face of severe and continuing defeats, and activists engage in repeated attempts to achieve their goals despite repeated losses (Beckwith, 2015). For example, in the LGBT movement for a very long time many protests and struggles often resulted in defeats or very limited gains, yet the movement persisted (Bernstein, 2003), while some victories had the opposite effect of decreasing mobilization (Kane, 2010). In contrast with public politics, in which activist groups seek to achieve their goals through the legal system, and thus target the state rather than private actors such as firms (Hiatt, Grandy, and Lee, 2015; Reid and Toffel, 2009), the focus of our paper is thus limited to private politics and on the extra-institutional process through which activists challenge firms directly to extract concessions from them, or push them to change their behavior (Baron, 2003).

Further research should ideally explore in greater detail the dynamic aspects of the strategic interaction between social movements and firms (e.g. Ingram et al., 2010). While the literature has highlighted how organizations respond to episodes of contention enacted by activists (Eesley and Lenox, 2006), and our study's contribution concerns the effects of firm decisions on activism, both parties likely learn from both victories and defeats, adjusting their strategies as the interaction unfolds. 
There is the possibility that social movements may not only be "spilling over", but shifting the tactics that they are employing, as well. Firms might also react to shifts in local mobilization patterns, just like activists react to firm decisions in our work. Our empirical setting offers a single, isolated example of this: that of Pacific Gas \& Electric (PG\&E), California's largest electric utility, which proposed multiple units in California in the 1960s and 1970s, beginning with Bodega Bay, which we discussed in the introduction to this paper.

Taking stock of its defeat at Bodega Bay, PG\&E decided to scrap its plans for another plant to be located at Nipomo Dunes, once again an area of great scenic beauty, fearing a similar outcome. Instead, they negotiated and struck a deal with their main opponent - the environmentalist group Sierra Club—and pledged not to build anything at Nipomo Dunes in exchange for the organization's support of a later project at the Diablo Canyon site. Splitting the opposition proved to be a successful strategy for PG\&E, showing the company had learned from its past mistakes that hardline stances were unlikely to pay off. Their plans were ultimately successful, in that the two units at Diablo Canyon were connected to the grid in 1985 and 1986 (respectively) after a 20-year struggle. While the lack of similar cases in our data made us unable to look into this issue further, we think examining the interaction as it unfolds over time - a repeated game of sorts, borrowing the lingo of game theorywould be generative, and we hope that scholars will take it up as a potential avenue for further work. In particular, scholars could examine the evolution of tactics used by both social movements and firms over time, and whether movements or firms might shift from protests in public spaces to relatively more structured forms of mobilization, such as participation in congressional hearings. 


\section{References}

Aldrich DP. 2008. Site Fights: Divisive Facilities and Civil Society in Japan and the West. Cornell University Press: Ithaca, NY.

Andrews KT, Beyerlein K, Tucker Farnum T. 2015. The Legitimacy of Protest: Explaining White Southerners' Attitudes Toward the Civil Rights Movement. Social Forces 00(00): sov097.

Baron DP. 2001. Private Politics, Corporate Social Responsibility, and Integrated Strategy. Journal of Economics \& Management Strategy 10(1): 7-45.

Baron DP. 2003. Private Politics. Journal of Economics \& Management Strategy 12(1): 31-66.

Beckwith K. 2015. Narratives of Defeat: Explaining the Effects of Loss in Social Movements. Journal of Politics 77(1): 2-13.

Blumer HG. 1969. Collective Behavior. In Principles of Sociology, 3rd ed., Lee AM (ed). Barnes \& Noble: New York, NY.

Briscoe F, Gupta A, Anner MS. 2015. Social Activism and Practice Diffusion: How Activist Tactics Affect Non-targeted Organizations. Administrative Science Quarterly 60(2): 300-332.

Briscoe F, Safford S. 2008. The Nixon-in-China Effect: Activism, Imitation, and the Institutionalization of Contentious Practices. Administrative Science Quarterly 53(3): 460-491.

Clemens ES, Minkoff DC. 2004. Beyond the Iron Law: Rethinking the Place of Organizations in Social Movement Research. In The Blackwell Companion to Social Movements, Snow DA, Soule SA, Kriesi H (eds). Blackwell: Oxford, UK: 155-170.

Daly J. 2015. Nuclear Fault Line - Bodega Head. Sonoma Magazine. Santa Rosa, CA. Available at: https://www.sonomamag.com/nuclear-fault-line/.

Davenport C. 2015. How Social Movements Die: Repression and Demobilization in the Republic of New Africa. Cambridge University Press: New York, NY.

Davenport C, Soule SA, Armstrong DA. 2011. Protesting While Black?: The Differential Policing of American Activism, 1960 to 1990. American Sociological Review 76(1): 152-178.

Davis GF, Diekmann KA, Tinsley CH. 1994. The Decline and Fall of the Conglomerate Firm in the 1980s: The Deinstitutionalization of an Organizational Form. American Sociological Review 59(4): 547-570.

Earl J, Martin A, McCarthy JD, Soule SA. 2004. The Use of Newspaper Data in the Study of Collective Action. Annual Review of Sociology 30(1): 65-80.

Eesley C, Lenox MJ. 2006. Firm Responses to Secondary Stakeholder Action. Strategic Management Journal 27(8): 765-781.

Eesley CE, Decelles KA, Lenox M. 2016. Through the Mud or in the Boardroom: Examining Activist Types and Their Strategies in Targeting Firms for Social Change. Strategic Management Journal 37(12): 24252440.

Ferguson J-P, Dudley T, Soule SA. 2017. Osmotic Mobilization and Union Support during the Long Protest Wave, 1960-1995. Administrative Science Quarterly : 1-57.

Gamson WA. 1975. The Strategy of Social Protest. Dorsey: Homewood, IL.

Gibbon P. 1988. Analysing the British Miners' Strike of 1984-5. Economy and Society 17(2): 139-194.

Golub GH, Van Loan CF. 1996. Matrix Computations. John Hopkins University Press: Baltimore, MD.

Gupta D. 2009. The Power of Incremental Outcomes: How Small Victories and Defeats Affect Social Movement Organizations. Mobilization 14(4): 417-432.

Hadden J, Tarrow S. 2007. Spillover or Spillout? The Global Justice Movement in the United States after 9/11. Mobilization 12(4): 359-376.

Hiatt SR, Grandy JB, Lee BH. 2015. Organizational Responses to Public and Private Politics: An Analysis of Climate Change Activists and U.S. Oil and Gas Firms. Organization Science 26(6): 1769-1786.

Hiatt SR, Sine WD, Tolbert PS. 2009. From Pabst to Pepsi: The Deinstitutionalization of Social Practices and the Creation of Entrepreneurial Opportunities. Administrative Science Quarterly 54(4): 635-667.

Howell D. 2012. Defiant Dominoes: Working Miners and the 1984-5 Strike. In Making Thatcher's Britain, Jackson B, Saunders R (eds). Cambridge University Press: Cambridge: 148-164.

Ingram P, Yue LQ, Rao H. 2010. Trouble in Store: Probes, Protests, and Store Openings by Wal-Mart, 1998 
- 2007. American Joumal of Sociology 116(1): 53-92.

Jerolmack C, Walker ET. 2018. Please in My Backyard: Quiet Mobilization in Support of Fracking in an Appalachian Community. American Journal of Sociology 124(2): 479-516.

Kauffman LA. 2017. Direct Action: Protest and the Reinvention of American Radicalism. Verso Books.

King BG. 2008. A Political Mediation Model of Corporate Response to Social Movement Activism. Administrative Science Quarterly 53(3): 395-421.

King BG, Pearce NA. 2010. The Contentiousness of Markets: Politics, Social Movements, and Institutional Change in Markets. Annual Review of Sociology 36(1): 249-267.

King BG, Soule SA. 2007. Social Movements as Extra-Institutional Entrepreneurs: The Effect of Protests on Stock Price Returns. Administrative Science Quarterly 52(3): 413-442.

Lenox MJ, Eesley CE. 2009. Private Environmental Activism and the Selection and Response of Firm Targets. Journal of Economics and Management Strategy 18(1): 45-73.

Liang K-Y, Zeger SL. 1986. Longitudinal Data Analysis Using Generalized Linear Models. Biometrika 73(1): $13-22$.

Luders J. 2006. The Economics of Movement Success: Business Responses to Civil Rights Mobilization. American Journal of Sociology 111(4): 963-998.

Mauss AL. 1975. Social Problems as Social Movements. Lippincott: Philadelphia, PA.

McAdam D, Boudet H. 2012. Putting Social Movements in their Place: Explaining Opposition to Energy Projects in the United States, 2000-2005. Cambridge University Press: Cambridge, UK.

McCarthy JD, Zald MN. 1977. Resource Mobilization and Social Movements: A Partial Theory. American Journal of Sociology 82(6): 1212-1241.

McPherson M. 1983. An Ecology of Affiliation. American Sociological Review 48(4): 519-532.

Meyer DS, Whittier N. 1994. Social Movement Spillover. Social Problems 41: 277-298.

Minkoff DC. 1997. The Sequencing of Social Movements. American Sociological Review 62(5): 779.

Moyer B. 2001. Doing Democracy: The MAP Model for Organizing Social Movements. New Society Publishers.

Nelkin D. 1981. Some Social and Political Dimensions of Nuclear Power: Examples from Three Mile Island. The American Political Science Review 75(1): 132-142.

Ortiz DG, Myers DJ, Walls NE, Diaz M-ED. 2005. Where Do We Stand with Newspaper Data? Mobilization 10(3): 397-419.

Pacheco DF, Dean TJ. 2015. Firm Responses to Social Movement Pressures: A Competitive Dynamics Perspective. Strategic Management Journal 36(7): 1093-1104.

Phillips J. 2014. Containing, Isolating and Defeating the Miners: the UK Cabinet Ministerial Group on Coal and the Three Phases of the 1984-5 Strike. Historical Studies in Industrial Relations 35(March): 117-141.

Piazza A, Perretti F. 2015. Categorical Stigma and Firm Disengagement: Nuclear Power Generation in the United States, 1970-2000. Organization Science. New York, NY 26(3): 724-742.

Rao H, Greve HR, Davis GF. 2001. Fool's Gold: Social Proof in the Initiation and Abandonment of Coverage by Wall Street Analysts. Administrative Science Quarterly 46(3): 502-526.

Reid EM, Toffel MW. 2009. Responding to Public and Private Politics: Corporate Disclosure of Climate Change Strategies. Strategic Management Journal 30(June): 1157-1178.

Robnett B. 1996. African-American Women in the Civil Rights Movement, 1954-1965: Gender, Leadership, and Micromobilization. American Journal of Sociology 101(6): 1661-1693.

Schudson M. 1993. Watergate In American Memory: How We Remember, Forget, And Reconstruct The Past. Basic Books: New York, NY.

Sewell WH. 1996. Historical Events as Transformations of Structures: Inventing Revolution at the Bastille. Theory and Society 25(6): 841-881.

Soule SA. 2012. Social Movements and Markets, Industries, and Firms. Organization Studies 33(12): 1715-1733.

Staggenborg S. 1988. The Consequences of Professionalization and Formalization in the Pro-Choice Movement. American Sociological Review 53(4): 585.

Staggenborg S. 1993. Critical Events and the Mobilization of the Pro-Choice Movement. Research in Political Sociology 6: 319-345.

Tarrow S. 2011. Power in Movement: Collective Action, Social Movements and Politics. Cambridge University Press: Cambridge, UK. 
Taylor SE. 1991. Asymmetrical Effects of Positive and Negative Events: The Mobilization-Minimization Hypothesis. Psychological Bulletin 110(1): 67-85.

Tilly C. 1978. From Mobilization to Revolution. Addison-Wesley.

Tompkins AS. 2016. Better Active than Radioactive! Anti-Nuclear Protest in 1970s France and West Germany. Oxford University Press: Oxford, UK.

Walker ET, Martin AW, McCarthy JD. 2008. Confronting the State, the Corporation, and the Academy: The Influence of Institutional Targets on Social Movement Repertoires. American Journal of Sociology 114(1): $35-76$.

Walker JS. 2006. Three Mile Island: A Nuclear Crisis in Historical Perspective. University of California Press: Berkeley, CA.

Walsh EJ. 1981. Resource Mobilization and Citizen Protest in Communities around Three Mile Island. Social Problems 29(1): 1-21.

Walsh EJ. 1986. The Role of Target Vulnerabilities in High-Technology Protest Movements : The Nuclear Establishment at Three Mile Island. Sociological Forum 1(2): 199-218.

Wang DJ, Piazza A, Soule SA. 2018. Boundary-Spanning in Social Movements. Annual Review of Sociology.

Wang DJ, Rao H, Soule SA. 2019. Crossing Categorical Boundaries: A Study of Diversification by Social Movement Organizations. American Sociological Review 84(3): 420-458.

Weart SR. 2012. The Rise of Nuclear Fear. Harvard University Press: Cambridge, MA.

Wellock T. 1998. Critical Masses: Opposition to Nuclear Power in California, 1958-1978. The University of Wisconsin Press.

White H. 1980. A Heteroskedasticity-Consistent Covariance Matrix Estimator and a Direct Test for Heteroskedasticity. Econometrica 48(4): 817-838.

Wright RA, Boudet HS. 2012. To Act or Not to Act: Context, Capability, and Community Response to Environmental Risk. American Journal of Sociology 118(3): 728-777.

Yue LQ, Rao H, Ingram P. 2013. Information Spillovers from Protests Against Corporations: A Tale of Walmart and Target. Administrative Science Quarterly 58(4): 669-701. 
Table 1. Descriptive statistics and pairwise correlations.

\begin{tabular}{|c|c|c|c|c|c|c|c|c|c|c|c|c|c|c|c|c|c|c|c|c|}
\hline & & Mean & S.D. & Min & Max & 1 & 2 & 3 & 4 & 5 & 6 & 7 & 8 & 9 & 10 & 11 & 12 & 13 & 14 & 15 \\
\hline 1 & Count of anti-nuclear protests & 0.005 & 0.129 & 0 & 11 & 1 & & & & & & & & & & & & & & \\
\hline 2 & Count of other protests & 0.335 & 5.08 & 0 & 327 & 0.18 & 1 & & & & & & & & & & & & & \\
\hline 3 & Unemployment (percent) & 0.076 & 0.037 & 0 & 0.382 & -0.004 & -0.022 & 1 & & & & & & & & & & & & \\
\hline 4 & African-American population (percent) & 0.065 & 0.116 & 0 & 0.864 & -0.008 & 0.046 & -0.02 & 1 & & & & & & & & & & & \\
\hline 5 & Total county population (logged) & 10.472 & 1.264 & 0 & 16.034 & 0.076 & 0.16 & -0.099 & -0.018 & 1 & & & & & & & & & & \\
\hline 6 & College-educated individuals (percent) & 0.094 & 0.071 & 0 & 0.563 & 0.059 & 0.063 & 0.011 & -0.054 & 0.393 & 1 & & & & & & & & & \\
\hline 7 & Median income (logged) & 9.607 & 0.563 & 0 & 11.171 & 0.019 & -0.001 & 0.189 & -0.084 & 0.278 & 0.74 & 1 & & & & & & & & \\
\hline 8 & Vote for president in the last election: Republican & 0.62 & 0.485 & 0 & 1 & -0.003 & -0.04 & 0.001 & -0.118 & 0.032 & 0.156 & 0.2 & 1 & & & & & & & \\
\hline 9 & Past nuclear protest activity (orthog.) & 0.044 & 1.357 & -0.058 & 50.734 & 0.249 & 0.304 & -0.025 & 0.004 & 0.148 & 0.165 & 0.102 & -0.013 & 1 & & & & & & \\
\hline 10 & Past non-nuclear protest activity (orthog.) & 0.019 & 1.359 & -23.231 & 76.343 & 0.084 & 0.675 & 0.004 & 0.046 & 0.098 & 0.058 & -0.003 & -0.042 & 0.001 & 1 & & & & & \\
\hline 11 & Anti-nuclear protests nationwide in the past 2 years & 11.102 & 17.829 & 0 & 91 & 0.035 & -0.004 & 0.293 & -0.201 & -0.007 & 0.143 & 0.088 & 0.048 & 0.004 & 0 & 1 & & & & \\
\hline 12 & Number of planned nuclear units nationwide & 5.677 & 10.932 & 0 & 41 & -0.016 & 0.01 & -0.304 & 0.073 & -0.031 & -0.399 & -0.499 & 0.006 & -0.037 & 0.007 & -0.253 & 1 & & & \\
\hline 13 & Number of planned nuclear units within 100 miles & 1.761 & 2.541 & 0 & 22 & 0.038 & 0.055 & -0.033 & -0.004 & 0.125 & -0.205 & -0.272 & -0.018 & -0.018 & 0.042 & 0.109 & 0.311 & 1 & & \\
\hline 14 & Number of completed nuclear units within 100 miles & 1.269 & 2.232 & 0 & 16 & 0.013 & 0.068 & -0.271 & 0.094 & 0.176 & -0.334 & -0.438 & -0.106 & -0.022 & 0.028 & -0.11 & 0.288 & 0.578 & 1 & \\
\hline 15 & Number of cancelled nuclear units within 100 miles & 1.233 & 1.868 & 0 & 9 & 0.036 & 0.032 & 0.15 & 0.092 & 0.164 & 0.397 & 0.521 & 0.089 & 0.122 & 0.024 & 0.026 & -0.32 & -0.176 & -0.23 & 1 \\
\hline
\end{tabular}


Table 2. Fixed effects negative binomial regression models for the number of anti-nuclear protests in atrisk counties.

\begin{tabular}{|c|c|c|c|c|c|c|}
\hline DV: count of anti-nuclear protests & Model 1 & Model 2 & Model 3 & Model 4 & Model 5 & Model 6 \\
\hline Unemployment (percent) & $\begin{array}{c}35.6286 \\
(6.757)\end{array}$ & $\begin{array}{c}35.5998 \\
(7.078)\end{array}$ & $\begin{array}{c}28.7538 \\
(7.115)\end{array}$ & $\begin{array}{c}21.3244 \\
(6.497)\end{array}$ & $\begin{array}{c}20.0291 \\
(6.670)\end{array}$ & $\begin{array}{c}15.0252 \\
(6.422)\end{array}$ \\
\hline African-American population (percent) & $\begin{array}{c}-6.0428 \\
(1.642)\end{array}$ & $\begin{array}{c}-5.2809 \\
(1.553)\end{array}$ & $\begin{array}{l}-3.9541 \\
(1.493)\end{array}$ & $\begin{array}{l}-2.8726 \\
(1.515)\end{array}$ & $\begin{array}{l}-2.1379 \\
(1.554)\end{array}$ & $\begin{array}{r}-2.0499 \\
(1.583)\end{array}$ \\
\hline Total county population (logged) & $\begin{array}{l}0.4698 \\
(0.192)\end{array}$ & $\begin{array}{l}0.6802 \\
(0.228)\end{array}$ & $\begin{array}{l}0.5865 \\
(0.220)\end{array}$ & $\begin{array}{l}0.3967 \\
(0.179)\end{array}$ & $\begin{array}{l}0.4635 \\
(0.188)\end{array}$ & $\begin{array}{l}0.4885 \\
(0.176)\end{array}$ \\
\hline College-educated individuals (percent) & $\begin{array}{l}9.7686 \\
(2.956)\end{array}$ & $\begin{array}{c}18.5581 \\
(3.810)\end{array}$ & $\begin{array}{c}15.6005 \\
(3.965)\end{array}$ & $\begin{array}{c}15.5707 \\
(3.872)\end{array}$ & $\begin{array}{c}14.1479 \\
(3.852)\end{array}$ & $\begin{array}{c}12.3618 \\
(3.842)\end{array}$ \\
\hline Median income (logged) & $\begin{array}{c}-1.4525 \\
(0.469)\end{array}$ & $\begin{array}{r}-2.1660 \\
(0.512)\end{array}$ & $\begin{array}{c}-2.0175 \\
(0.543)\end{array}$ & $\begin{array}{c}-1.8606 \\
(0.548)\end{array}$ & $\begin{array}{c}-2.0724 \\
(0.556)\end{array}$ & $\begin{array}{c}-2.3825 \\
(0.560)\end{array}$ \\
\hline Vote for president in the last election: Republican & $\begin{array}{l}0.1108 \\
(0.231)\end{array}$ & $\begin{array}{r}-0.0226 \\
(0.235)\end{array}$ & $\begin{array}{l}0.0126 \\
(0.241)\end{array}$ & $\begin{array}{l}0.0129 \\
(0.244)\end{array}$ & $\begin{array}{c}-0.0019 \\
(0.246)\end{array}$ & $\begin{array}{l}0.0177 \\
(0.249)\end{array}$ \\
\hline Past nuclear protest activity (orthog.) & & $\begin{array}{c}-0.0708 \\
(0.019)\end{array}$ & $\begin{array}{c}-0.0651 \\
(0.019)\end{array}$ & $\begin{array}{c}-0.0441 \\
(0.018)\end{array}$ & $\begin{array}{l}-0.0405 \\
(0.018)\end{array}$ & $\begin{array}{c}-0.0546 \\
(0.019)\end{array}$ \\
\hline Past non-nuclear protest activity (orthog.) & & $\begin{array}{r}-0.0419 \\
(0.015)\end{array}$ & $\begin{array}{c}-0.0336 \\
(0.015)\end{array}$ & $\begin{array}{c}-0.0363 \\
(0.016)\end{array}$ & $\begin{array}{c}-0.0360 \\
(0.016)\end{array}$ & $\begin{array}{r}-0.0380 \\
(0.015)\end{array}$ \\
\hline $\begin{array}{l}\text { Anti-nuclear protests nationwide in the past } 2 \\
\text { years }\end{array}$ & & & $\begin{array}{l}0.0066 \\
(0.003)\end{array}$ & $\begin{array}{l}0.0037 \\
(0.003)\end{array}$ & $\begin{array}{l}0.0039 \\
(0.003)\end{array}$ & $\begin{array}{l}0.0060 \\
(0.004)\end{array}$ \\
\hline Number of planned nuclear units nationwide & & & $\begin{array}{r}-0.0309 \\
(0.014)\end{array}$ & $\begin{array}{c}-0.0506 \\
(0.015)\end{array}$ & $\begin{array}{l}-0.0502 \\
(0.015)\end{array}$ & $\begin{array}{r}-0.0509 \\
(0.015)\end{array}$ \\
\hline Number of planned nuclear units within 100 miles & & & & $\begin{array}{l}0.1682 \\
(0.032)\end{array}$ & $\begin{array}{l}0.1955 \\
(0.036)\end{array}$ & $\begin{array}{l}0.2453 \\
(0.039)\end{array}$ \\
\hline $\begin{array}{l}\text { Number of completed nuclear units within } 100 \\
\text { miles }\end{array}$ & & & & & $\begin{array}{c}-0.1514 \\
(0.068)\end{array}$ & $\begin{array}{r}-0.2009 \\
(0.073)\end{array}$ \\
\hline $\begin{array}{l}\text { Number of cancelled nuclear units within } 100 \\
\text { miles }\end{array}$ & & & & & & $\begin{array}{l}0.2395 \\
(0.063)\end{array}$ \\
\hline Constant & $\begin{array}{l}3.0180 \\
(4.554)\end{array}$ & $\begin{array}{l}6.7748 \\
(5.173)\end{array}$ & $\begin{array}{l}7.3006 \\
(5.352)\end{array}$ & $\begin{array}{l}7.6946 \\
(5.229)\end{array}$ & $\begin{array}{l}9.4473 \\
(5.248)\end{array}$ & $\begin{array}{r}12.2970 \\
(5.180)\end{array}$ \\
\hline County fixed effects & Yes & Yes & Yes & Yes & Yes & Yes \\
\hline Chi-squared & 113.3 & 131.5 & 150.4 & 166.9 & 169.6 & 183.8 \\
\hline Log-likelihood & -531.3 & -521.3 & -513.2 & -500.1 & -497.5 & -490.2 \\
\hline Degrees of freedom & 6 & 8 & 10 & 11 & 12 & 13 \\
\hline
\end{tabular}


Table 3. Fixed effects negative binomial regression models for the number of unrelated protests in at-risk counties.

\begin{tabular}{|c|c|c|c|c|c|c|}
\hline DV: count of unrelated protests & Model 7 & Model 8 & Model 9 & Model 10 & Model 11 & Model 12 \\
\hline \multirow[t]{2}{*}{ Unemployment (percent) } & -1.5506 & -1.4924 & -4.0685 & -4.2292 & -3.6356 & -3.7424 \\
\hline & $(0.858)$ & $(0.862)$ & $(0.959)$ & $(0.969)$ & $(1.001)$ & $(1.003)$ \\
\hline \multirow[t]{2}{*}{ African-American population (percent) } & -0.4774 & -0.4766 & -0.0107 & 0.0599 & 0.0525 & 0.0522 \\
\hline & $(0.201)$ & $(0.201)$ & $(0.213)$ & $(0.221)$ & $(0.220)$ & $(0.220)$ \\
\hline \multirow[t]{2}{*}{ Total county population (logged) } & 0.7205 & 0.7175 & 0.7189 & 0.7150 & 0.7041 & 0.7050 \\
\hline & $(0.028)$ & $(0.028)$ & $(0.029)$ & $(0.029)$ & $(0.029)$ & $(0.029)$ \\
\hline \multirow[t]{2}{*}{ College-educated individuals (percent) } & 0.5479 & 0.2189 & -0.3757 & -0.3548 & -0.1024 & -0.1886 \\
\hline & $(0.318)$ & $(0.345)$ & $(0.379)$ & $(0.380)$ & $(0.405)$ & $(0.407)$ \\
\hline \multirow[t]{2}{*}{ Median income (logged) } & -0.2538 & -0.2368 & -0.1729 & -0.1720 & -0.1391 & -0.1573 \\
\hline & $(0.048)$ & $(0.050)$ & $(0.055)$ & $(0.055)$ & $(0.059)$ & $(0.059)$ \\
\hline \multirow[t]{2}{*}{ Vote for president in the last election: Republican } & -0.0690 & -0.0638 & -0.0829 & -0.0855 & -0.0860 & -0.0864 \\
\hline & $(0.033)$ & $(0.033)$ & $(0.034)$ & $(0.034)$ & $(0.034)$ & $(0.034)$ \\
\hline \multirow[t]{2}{*}{ Past nuclear protest activity (orthog.) } & & 0.0133 & 0.0150 & 0.0157 & 0.0153 & 0.0151 \\
\hline & & $(0.005)$ & $(0.005)$ & $(0.005)$ & $(0.005)$ & $(0.005)$ \\
\hline \multirow[t]{2}{*}{ Past non-nuclear protest activity (orthog.) } & & -0.0002 & 0.0007 & 0.0004 & 0.0001 & -0.0002 \\
\hline & & $(0.003)$ & $(0.004)$ & $(0.004)$ & $(0.004)$ & $(0.004)$ \\
\hline \multirow[t]{2}{*}{$\begin{array}{l}\text { Anti-nuclear protests nationwide in the past } 2 \\
\text { years }\end{array}$} & & & 0.0062 & 0.0060 & 0.0061 & 0.0061 \\
\hline & & & $(0.001)$ & $(0.001)$ & $(0.001)$ & $(0.001)$ \\
\hline \multirow[t]{2}{*}{ Number of planned nuclear units nationwide } & & & -0.0002 & -0.0009 & -0.0002 & -0.0002 \\
\hline & & & $(0.002)$ & $(0.002)$ & $(0.002)$ & $(0.002)$ \\
\hline \multirow[t]{2}{*}{ Number of planned nuclear units within 100 miles } & & & & 0.0069 & 0.0030 & 0.0051 \\
\hline & & & & $(0.006)$ & $(0.006)$ & $(0.006)$ \\
\hline \multirow[t]{2}{*}{$\begin{array}{l}\text { Number of completed nuclear units within } 100 \\
\text { miles }\end{array}$} & & & & & 0.0212 & 0.0224 \\
\hline & & & & & $(0.009)$ & $(0.009)$ \\
\hline \multirow[t]{2}{*}{$\begin{array}{l}\text { Number of cancelled nuclear units within } 100 \\
\text { miles }\end{array}$} & & & & & & 0.0144 \\
\hline & & & & & & $(0.011)$ \\
\hline \multirow[t]{2}{*}{ Constant } & -6.7942 & -6.8921 & -7.3532 & -7.3236 & -7.6269 & -7.4748 \\
\hline & $(0.539)$ & $(0.545)$ & $(0.578)$ & $(0.579)$ & $(0.612)$ & $(0.614)$ \\
\hline County fixed effects & Yes & Yes & Yes & Yes & Yes & Yes \\
\hline Chi-squared & 727.9 & 739.9 & 773.7 & 776.2 & 786.6 & 788.3 \\
\hline Log-likelihood & -11202 & -11198 & -10940 & -10940 & -10937 & -10936 \\
\hline Degrees of freedom & 6 & 8 & 10 & 11 & 12 & 13 \\
\hline
\end{tabular}


Table 4. Fixed effects negative binomial regression models for the count of other (non anti-nuclear) protests in each county at time t, broken down by main claim.

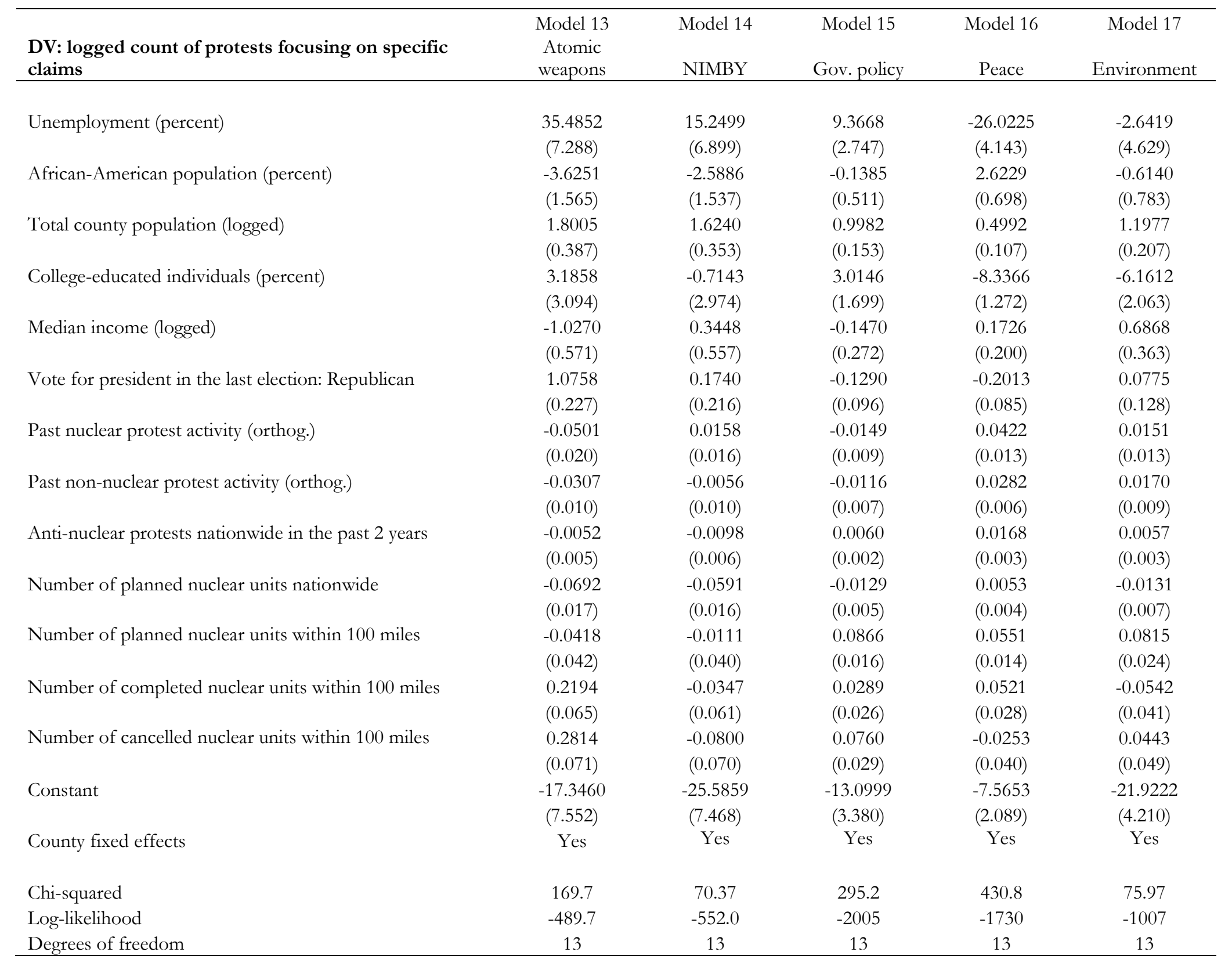


Table 5. Alternative full model specifications: fixed effects OLS models with year dummies and generalized estimating equations (GEE) models with year and state dummies.

\begin{tabular}{|c|c|c|c|c|}
\hline \multirow[b]{3}{*}{ DV: logged count of protests by type } & \multicolumn{2}{|c|}{ Fixed effects OLS } & \multicolumn{2}{|c|}{ GEE } \\
\hline & $\begin{array}{l}\text { Anti-nuclear } \\
\text { protests }\end{array}$ & $\begin{array}{l}\text { Other } \\
\text { protests }\end{array}$ & $\begin{array}{l}\text { Anti-nuclear } \\
\text { protests }\end{array}$ & $\begin{array}{l}\text { Other } \\
\text { protests }\end{array}$ \\
\hline & Model 18 & Model 19 & Model 20 & Model 21 \\
\hline \multirow[t]{2}{*}{ Unemployment (percent) } & -0.0418 & -0.0554 & -0.0435 & -0.0704 \\
\hline & $(0.015)$ & $(0.057)$ & $(0.011)$ & $(0.051)$ \\
\hline \multirow[t]{2}{*}{ African-American population (percent) } & -0.0104 & -0.0426 & -0.0021 & -0.0159 \\
\hline & $(0.004)$ & $(0.017)$ & $(0.003)$ & $(0.015)$ \\
\hline \multirow[t]{2}{*}{ Total county population (logged) } & -0.0024 & 0.0432 & 0.0019 & 0.0763 \\
\hline & $(0.002)$ & $(0.006)$ & $(0.000)$ & $(0.004)$ \\
\hline \multirow[t]{2}{*}{ College-educated individuals (percent) } & 0.0598 & -0.1928 & 0.0086 & -0.2275 \\
\hline & $(0.010)$ & $(0.040)$ & $(0.007)$ & $(0.035)$ \\
\hline \multirow[t]{2}{*}{ Median income (logged) } & -0.0199 & 0.0064 & -0.0101 & -0.0089 \\
\hline & $(0.003)$ & $(0.011)$ & $(0.002)$ & $(0.010)$ \\
\hline \multirow[t]{2}{*}{ Vote for president in the last election: Republican } & 0.0015 & 0.0084 & 0.0008 & 0.0054 \\
\hline & $(0.001)$ & $(0.002)$ & $(0.001)$ & $(0.002)$ \\
\hline \multirow[t]{2}{*}{ Past nuclear protest activity (orthog.) } & 0.0009 & -0.0019 & 0.0063 & 0.0015 \\
\hline & $(0.000)$ & $(0.001)$ & $(0.000)$ & $(0.001)$ \\
\hline \multirow[t]{2}{*}{ Past non-nuclear protest activity (orthog.) } & 0.0046 & -0.0095 & 0.0035 & -0.0025 \\
\hline & $(0.000)$ & $(0.001)$ & $(0.000)$ & $(0.001)$ \\
\hline Year dummies & Yes & Yes & Yes & Yes \\
\hline State dummies & No & No & Yes & Yes \\
\hline \multirow[t]{2}{*}{ Number of planned nuclear units within 100 miles } & 0.0010 & 0.0001 & 0.0010 & 0.0002 \\
\hline & $(0.000)$ & $(0.001)$ & $(0.000)$ & $(0.001)$ \\
\hline \multirow{2}{*}{$\begin{array}{l}\text { Number of completed nuclear units within } 100 \\
\text { miles }\end{array}$} & & & & \\
\hline & $\begin{array}{c}-0.0008 \\
(0.000)\end{array}$ & $\begin{array}{l}0.0029 \\
(0.001)\end{array}$ & $\begin{array}{c}-0.0004 \\
(0.000)\end{array}$ & $\begin{array}{l}0.0033 \\
(0.001)\end{array}$ \\
\hline \multirow{3}{*}{$\begin{array}{l}\text { Number of cancelled nuclear units within } 100 \\
\text { miles }\end{array}$} & & & & \\
\hline & 0.0012 & -0.0023 & 0.0010 & -0.0020 \\
\hline & $(0.000)$ & $(0.001)$ & $(0.000)$ & $(0.001)$ \\
\hline \multirow[t]{2}{*}{ Constant } & 0.1939 & -0.4644 & 0.0619 & -0.6960 \\
\hline & $(0.025)$ & $(0.100)$ & $(0.014)$ & $(0.086)$ \\
\hline
\end{tabular}


Figure 1. Number of anti-nuclear protests in the U.S. by year based on the NYT data.

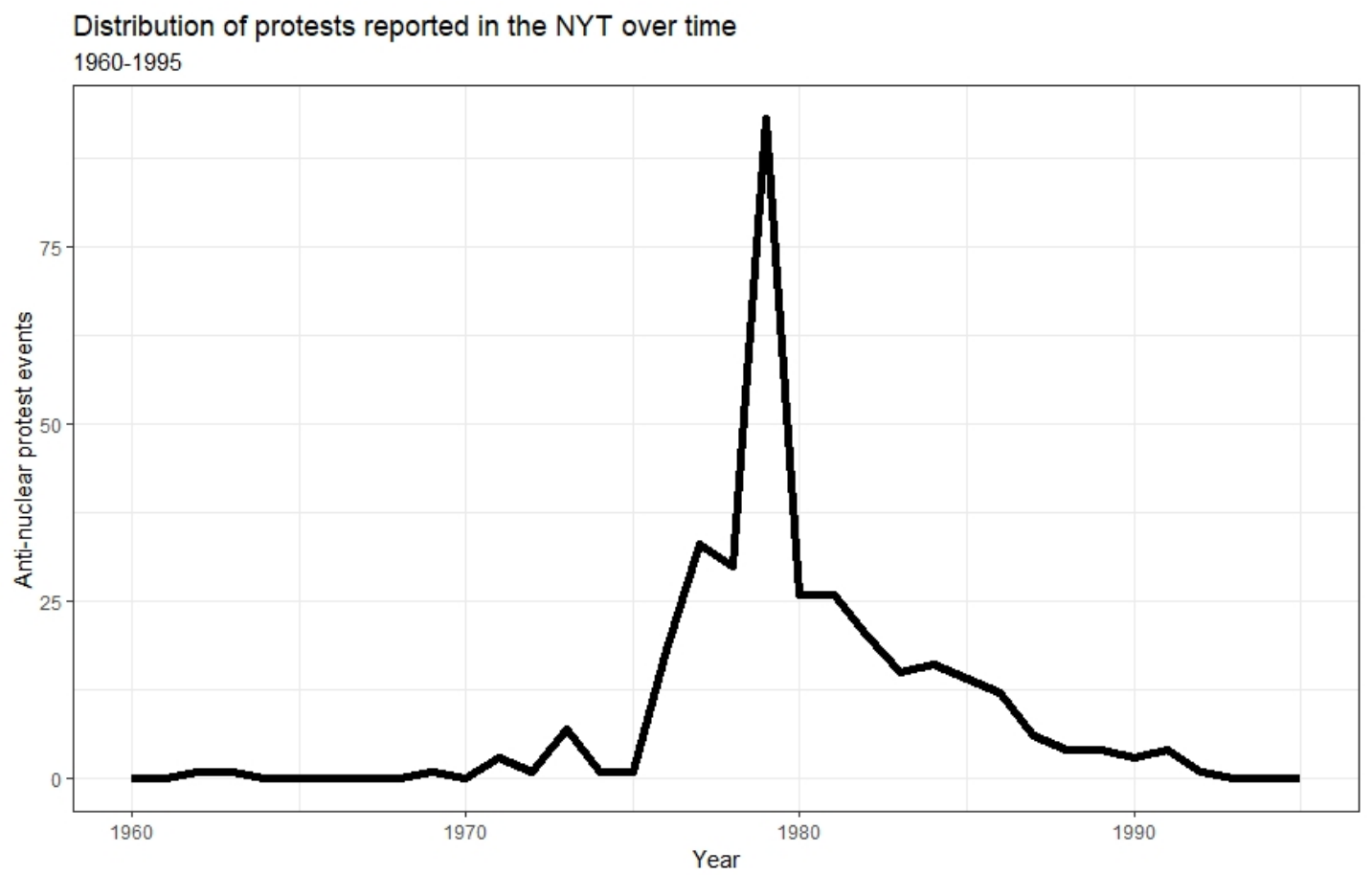

Figure 2. Temporal trends in the proposal, cancellation and completion of U.S. nuclear reactors, 1953-1995.

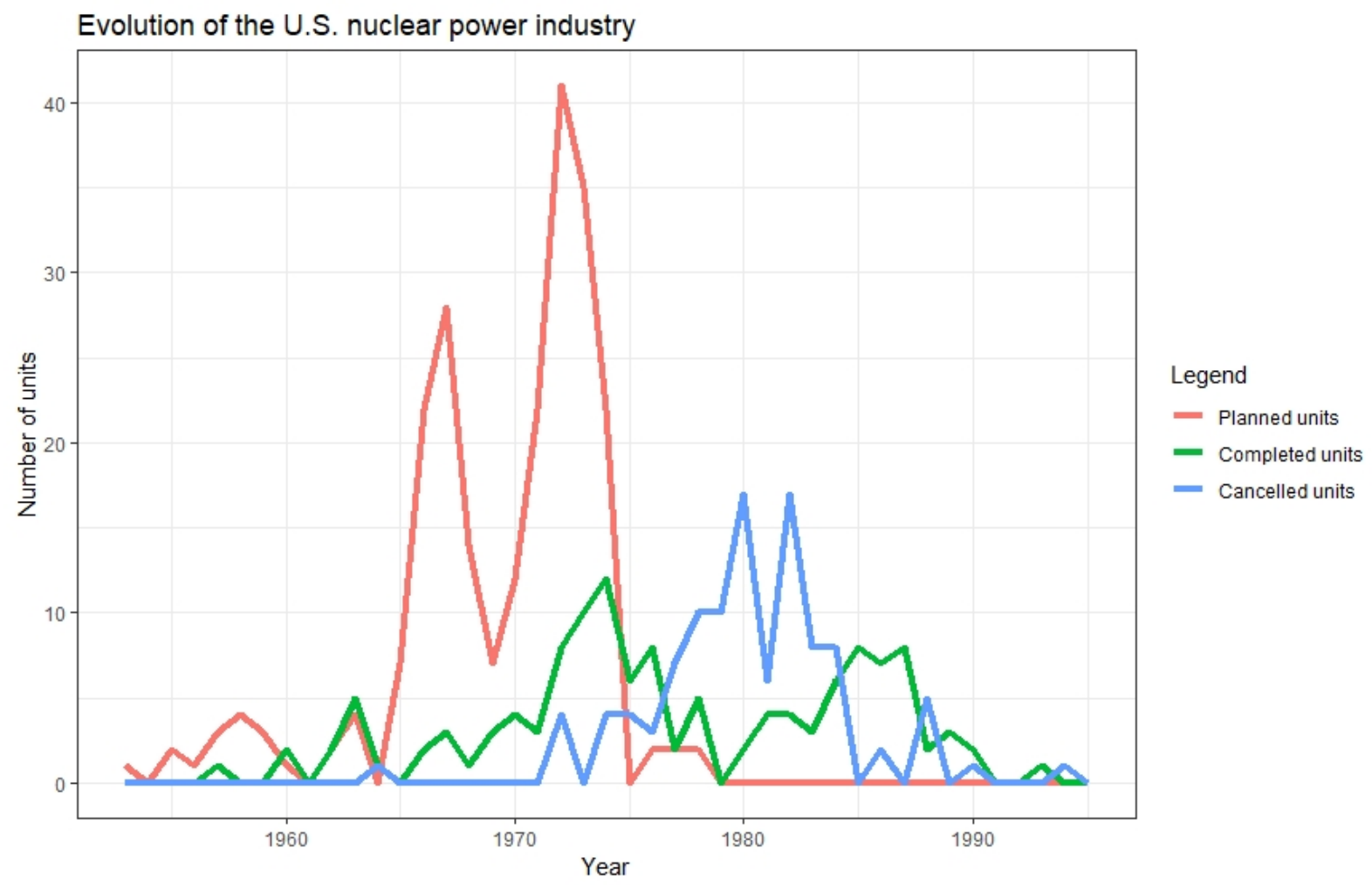


Figure 3. Proposed nuclear units (crosses) and anti-nuclear protests (dots) in the United States, 1960 to 1995.

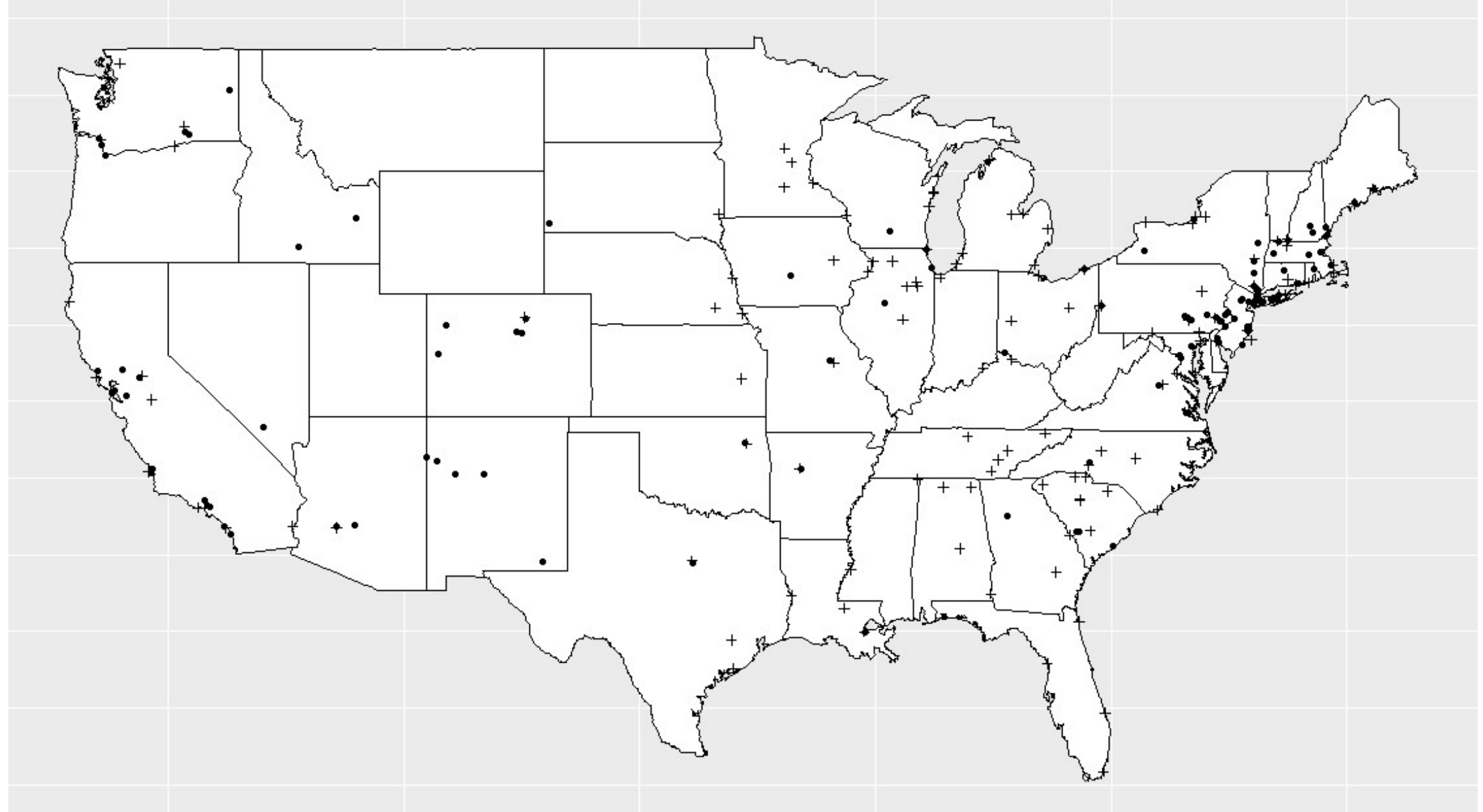


Figure 4. Coverage of anti-nuclear protests (\# of articles) by year in U.S. local newspapers, from Newspapers.com.

Mentions of anti-nuclear protests in local newspapers over time 1960-1995

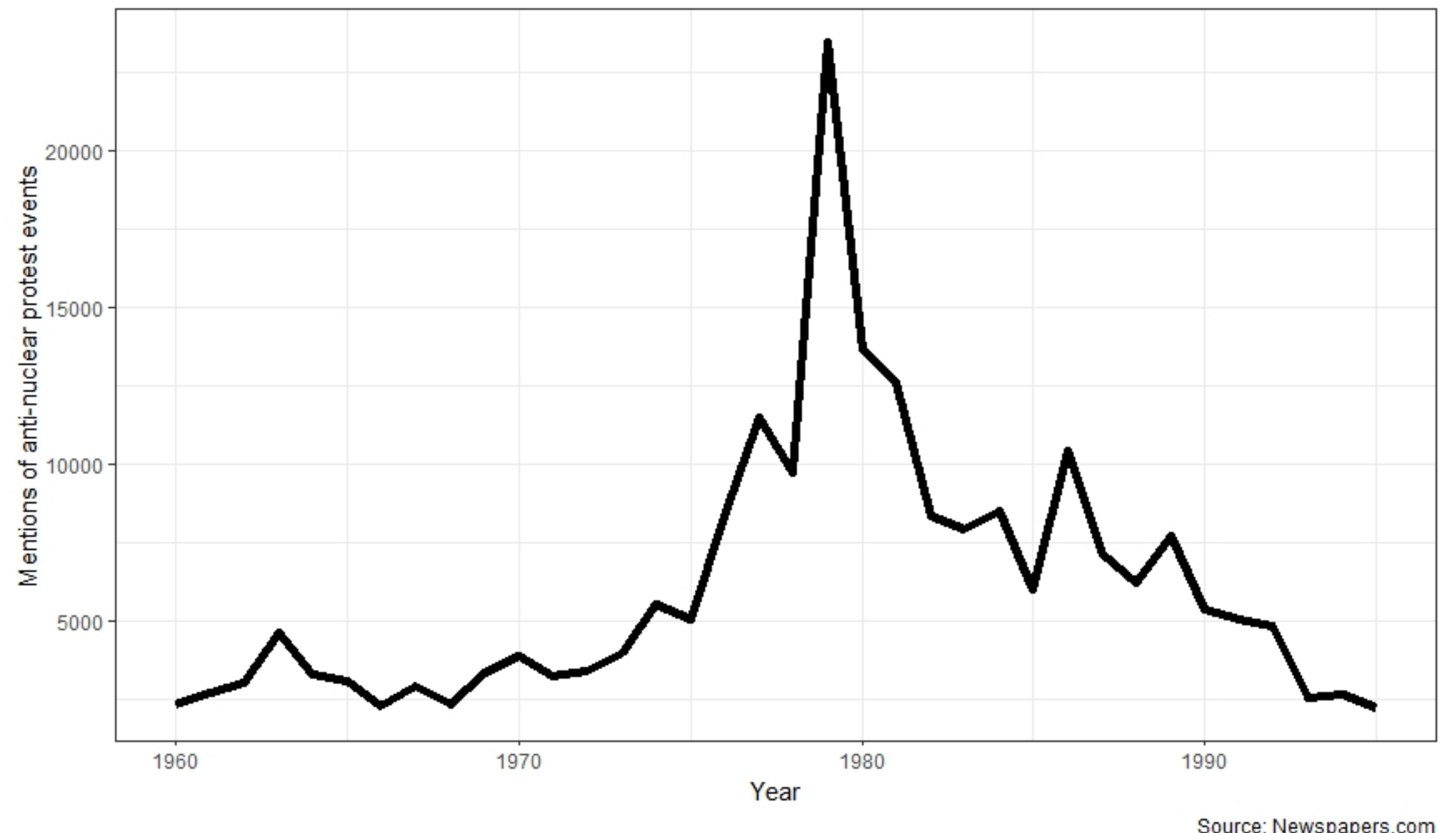

